\title{
A laktózintoleranciáról: Múlt és jelen - I. rész
}

\author{
Buzás György Miklós dr. \\ Ferencvárosi Egészségügyi Szolgáltató Kiemelten Közhasznú Nonprofit Kft., Budapest
}

\begin{abstract}
A tejcukor-érzékenység a leggyakoribb felszívódási zavar. A szerző a betegség történetének ismertetése után leírja a laktózintolerancia megjelenését a fajfejlődés során, majd vázolja a laktóz biokémiai jellegzetességeit. Az emberi és bakteriális laktáz enzim tulajdonságainak ismertetése után az epidemiológiai részben kitér a kórkép egyenlőtlen földrajzi eloszlására, régebbi és jelenlegi hazai elterjedésére. A felnőttkori laktózintoleranciát a 2. kromoszómán található laktáz gén felett elhelyezkedő MCM6 gén polimorfizmusa okozza: meghatározása polimeráz láncreakcióval lehetséges. A tejcukor-érzékenység extraintestinalis tünetei kevésbé ismertek. Az invazív diagnosztikai módszerek (laktázaktivitás mérése vékonybél-biopsziából, laktóztolerancia-teszt) bár pontosak, átadták helyüket a nem invazív módszereknek: a $\mathrm{H}_{2}$-kilégzési teszt arany strandardnak számít. A genetikai tesztet egyre kiterjedtebben használják hazánkban is, és a közeljövőben a metánkilégzési teszt is elérhető lehet. A tejcukor-érzékenység társulhat gyulladásos bélbetegségekkel, lisztérzékenységgel és irritábilis bél szindrómával: meg kell állapítani, hogy létezik-e patogenetikai összefüggés e betegségek között a helyes diéta és terápia megválasztása céljából. Orv. Hetil., 2015, 156(38), 1532-1539.
\end{abstract}

Kulcsszavak: coeliakia, gyulladásos bélbetegség, irritábilis bél, laktáz, laktóz, polimorfizmus, tejcukor-érzékenység

\section{Lactose intolerance: past and present. Part I}

Lactose intolerance is the most prevalent intestinal malabsorption disorder. After presentation of its history, the author describes the emergence of lactose intolerance during the evolution of species, and the biochemistry of lactose as well as features of human and bacterial lactase enzymes are then described. The unequal distribution of lactose intolerance in different continents and population is discussed, followed by presentation of past and present prevalence data in Hungary. Adult-type hypolactasia is caused by a polymorphism of the MCM6 gene located upstream from the lactase gene on the long arm of the chromosome 2. It can be determined with the polymerase chain reaction. The intestinal symptoms of lactose intolerance are well known, but its extra-intestinal manifestations are less recognised. Invasive diagnostic methods (determination of lactase activity from small intestinal biopsies, lactose tolerance test), are accurate, but have been replaced by the non-invasive methods; their gold standard is the $\mathrm{H}_{2}$ breath test. Genetic testing is being used more and more frequently in Hungary too, and, presumably, the methane breath test will be also available in the near future. Lactose intolerance can be accompanied by inflammatory bowel diseases, coeliac disease and irritable bowel syndrome; it could be established whether this association is causal or not in order to start a correct diet and therapy.

Keywords: coeliac disease, inflammatory bowel disease, irritable bowel syndrome, lactase, lactose, lactose intolerance, polymorphism

Buzás, Gy. M. [Lactose intolerance: past and present. Part I]. Orv. Hetil., 2015, 156(38), 1532-1539.

(Beérkezett: 2015. július 5.; elfogadva: 2015. július 30.)

\section{Rövidítések}

$\mathrm{A}=$ adenin; $\mathrm{BL}=$ bakteriális laktáz; $\mathrm{C}=$ citozin; $\mathrm{CD}=$ Crohnbetegség; $\mathrm{CU}=$ colitis ulcerosa; $\mathrm{EC}=($ enzyme classification $)$ az enzimek osztályozása; G = guanin; IBD = gyulladásos bélbetegség; IBS = irritábilis bél szindróma; LI = laktózintolerancia; $\mathrm{PCR}=$ polimeráz láncreakció; $\mathrm{T}$ = timidin; $\mathrm{UDP}=$ uridinil-difoszfát 
A laktózintolerancia a leggyakoribb felszívódási zavar [1]. Eredete visszavezethető az emlősállatok megjelenéséig, a szoptatás és a tej/tejtermékek fogyasztásának elterjedéséig. Bár világszerte mintegy 400 millió embert érint [2], gyakorisága ellenére a kórképnek aránytalanul kevés figyelmet szenteltek: jelentőségére, jellegzetességeire, szövődményeire az utóbbi évtizedekben derült fény [3]. Közleményünkben e kórkép történetét és jelenlegi ismereteit foglaljuk össze a régebbi és újabb irodalom alapján. Az Orvosi Hetilapban a laktózintoleranciáról 1968-1992 között jelentek meg tanulmányok [4, $5,6]$ : ez indokolja az összefoglalást.

\section{Történet}

A tej fogyasztása után fellépő hasmenést már Hippokrátész (Kr. e. 460-375) leírta, de sem a mester, sem utódai nem tulajdonítottak annak jelentőséget $[2,3]$. A tejben lévő laktózt 1633-ban mutatta ki a páduai Fabrizio Bartoletti (1576-1630) fiziológus, történész és filozófus. A saccharum lactis nevet 1700-ban adta Lodovico Testi (1640-1707) velencei gyógyszerész, aki ízületi fájdalomban ajánlotta adását. 1780-ban Carl Wilhelm Scheele (1742-1786) állapította meg cukor jellegét, 1812-ben Heinrich Vogel (1778-1867) kimutatta, hogy a glükóz a laktóz hidrolíziséből származik. 1856-ban Louis Pasteur (1822-1895) kristályosította a galaktózt. A laktóz kémiai szerkezetét 1894-ben Emil Hermann Fischer (18511910) határozta meg: 1902-ben a glükóz, fruktóz és több más cukrok szerkezetének meghatározásáért kémiai Nobel-díjat kapott. A laktóz elnevezést 1843-ban javasolta Jean Baptiste André Dumas (1800-1884) francia kémikus [3].

A XIX. század végén állatkísérletekben kimutatták, hogy a hasnyálmirigy nem termel laktázt, az amiláz pedig nem bontja le a laktózt. Ennek alapján Fischer feltételezte 1896-ban, hogy a bél nyálkahártyája termelhet egy olyan fermentumot, amely a diszacharidot lebontja. A századfordulón végzett, ellentmondásos eredményú német, francia és angol kísérletek után a laktáz enzimet 1906-ban mutatta ki a londoni egyetem élettani laboratóriumában R. H. Aders Plimmer, aki egységes módszert használva macska, kutya, bárány, szamár, juh, fóka, nyúl, sertés és tengerimalac beléból kivonatot készített és azt 2-3 napig laktózoldattal inkubálta, mérve a vegyület lebomlásának sebességét [7].

\section{Fajfejlődés}

Az állatvilágban alacsonyabb rendű fajoknál leírták, hogy egyes halak, galambok, rovarok egyedeiket tápláló váladékot termelnek, de csak az emlősöknél alakult ki olyan szerv, amely kizárólag az utódok táplálására és védelmére (ellenanyagok) szolgál. A primitív emlősöknél az emlő váladéka kezdetben nem táplálék, hanem védőanyag volt, azzal az anyaállat az újszülöttet bekente. Feltételezik, hogy a tej első funkciója a tojások nedves környezet- ben való tartása volt: ezt a tojást rakó emlősöknél figyelték meg. Évezredek alatt a tej termelése fokozatosan több, összetétele komplexebb lett és kialakult annak tápláló és immunológiai funkciója $[8,9]$. A szoptatás az utódok számára folyamatos táplálékot, védelmet, gondoskodást is biztosított, szemben például a madarakkal, hüllőkkel, amelyeknél a tojásból kikelt utódok táplálására a szülőnek hosszabb-rövidebb időre el kellett hagynia a fészket, ezáltal veszélyeztetve a fiókákat [9]. A laktóz minden emlős tejében megtalálható, kivéve az oroszlánfókát: ennek oka nem ismert.

Az embernél a tej fogyasztása a neolitikumban terjedt el, amikor a gyưjitögető-vadászó életmódról váltottak a növénytermesztő-állattenyésztő életmódra: ennek első jeleit a régészek Kr. e. 11000 körüli időszakra becsülik és Kr. e. 5-6000 évvel vált általánossá: ebben az időszakban léphettek fel a genetikai eltérések, amelyeknek következtében a tejcukor-érzékenység kialakult [10].

\section{A laktóz természetes előfordulása és biokémiája}

A laktóz-diszacharid a természetben poliszacharidokhoz, glikoproteinekhez és glikolipidekhez kötött formában fordul elő: ez utóbbiak a glüko- és galaktoceramidok, amelyek az endocitózisban keletkező hólyagocskák membránját képezik, például a laktóz az N-acetil-glükozaminhoz kötődve a neuramin-laktózt képezi. Szabad formában a laktóz csak az emlősök tejében található alfa és béta formában, amelyek egymásba átalakulhatnak. Vízben oldható, de kevésbé oldékony, mint a glükóz vagy fruktóz. Sokkal kevésbé édes, mint a szukróz [2].

A laktózt kizárólag az emlőmirigy szintetizálja a laktózszintetáz enzim közremúködésével. Az enzimnek két alegysége van, a galaktozil-transzferáz és az alfa-laktalbumin. Az első alegység normálisan az UDP-foszfát, galaktóz és $\mathrm{N}$-acetil-glükózamin részvételével $\mathrm{N}$-acetil-laktózamint képez, ez a glikoproteinek képződéséhez szükséges. A galaktozil-transzferáz minden szövetben jelen van, a laktózszintetáz (EC 2.4.1.22) csak az emlőmirigyekben található: múködését egy gén szabályozza, amely inaktív, de terhesség alatt aktiválódik, szülés hatására a galaktozil-transzferáz a prolaktin indukálta alfa-laktalbuminnal komplexumot alkot, amely az UDP-galaktózból + glükózból laktózt képez $[9,10,11]$.

A laktóz fontos energiaforrás: szoptatáskor a csecsemők energiaszükségletének 40\%-át biztosítja. Glykaemiás indexe alacsony, más cukroknál kevésbé emeli a vércukorszintet. Fontos az egészséges bélflóra kialakulásában, a kalcium, magnézium és cink felszívódásában.

\section{A laktáz biokémiája}

A laktáz a béta-galaktozidázok speciális típusa, az enzimek nemzetközi osztályozása szerint a hidrolázok csoportjába tartozik (EC 3.2.1.62). Emberben 3 laktáz for- 
dul elő: az enterocyták kefeszegélyében az enzim C-terminális részével a membránban horgonyozva, aktív részével a lumen felé fordulva a laktózt $\mathrm{D}(+)$-glükózra és $\mathrm{D}(+)$-galaktózra bontja. Csak az emlősök vékonybelében található. A citoplazmában lévő béta-galaktozidáz nem képes a laktóz hidrolízisére. A lizoszómában található enzim funkciója nem ismert. A laktázt egy polipeptid lánc alkotja, két aktív centruma van: az egyik a laktózt, a másik a diabetológiából ismert florizint hidrolizálja, szerkezetében az 1927 aminosav van, szekvenciája ismert. Az emberi laktáz 160 kDa molekulasúlyú, aktív centrumában az 1749-es pozícióban glutamát van, amely a béta-glikozid galaktózhoz kapcsolódva $\mathrm{Mg}^{2+}$ jelenlétében hidrolizálja a laktózt. Terhességben a maltáz-szukráz-aktivitás a 10 . héten jelenik meg, a laktáz a 12 . héten mutatható ki és aktivitása fokozatosan növekszik a szülésig, majd 5-12 éves korig csökken.

A florizint aril-glikozid, hidrolíziséből glükóz és a diabetogén floretin származik, ezért a biokémikusok számára a laktáz neve laktóz-florizin-hidroláz. A florizin a vesében lévő nátrium-glükóz kotranszporterek kompetitív gátlása révén fejti ki diabetogén hatását [3]. Adásával Josefvon Mering (1849-1908) kidolgozta az első kísérletes diabetesmodellt (1880).

A laktáz lusta és lassú enzim, aktivitása arányos az egyes emlősfajok tejében a laktóz koncentrációjával [2]. A karboanhidráz katalizációs sebessége 600 000-szer, a laktát dehidrogenázé 1000-szer nagyobb, mint a laktázé, ezért egyes kémikusok inkább oldószernek, mint enzimnek tartják, de az evolúció során aktivitása fejlődött, és elegendő az emberi tejben lévő 190 mmol laktóz lebontására. Az emberi bélben körülbelül 2500 egységnyi laktáz van, amely 15 perc alatt képes lebontani egy pohár tejben lévő laktózt. Súlyos hypolactasiában (250 egység) a lebontáshoz 2 óra kell: ez idő alatt a laktóz egy része a vastagbélbe juthat. A laktáz optimális pH-értéke 6,0, ami egyezik a duodenalis $\mathrm{pH}$-val, de aktivitásának 50\%-át megőrzi a vékonybélben $\mathrm{pH}=7-8$ között is. A laktáz hidrolizálja a cellulózt, di-, tri- és tetraszacharidokat: ennek jelentősége emberben nem ismert. Nem bontja le a laktulózt. A kolchicin és Tris-puffer kompetitíven gátolja az enzimet.

\section{A bakteriális laktáz}

Mind a normális bélflóra, mind egyes kórokozók termelnek laktázt (1. táblázat). A székletben lévő laktózt fermentáló baktériumokat 1905-ben írták le [12]. A bakteriális és emberi béta-galaktozidáz szerkezete és aminosav szekvenciája különböző. A baktériumok előszeretettel használnak szénhidrátokat (glükóz, fruktóz, pentózok, laktóz) energiaforrásként. A laktózt intracellulárisan galaktózra és glükózra, majd azokat anaerob metabolikus útvonalakon lebontják: ebből ATP formájában energia, melléktermékként laktát, $\mathrm{CO}_{2}, \mathrm{H}_{2}, \mathrm{CH}_{4}$, rövid láncú zsírsavak, ső́t alkohol is keletkezik: ezek aránya egyénenként változik, és ezek okozzák az LI változatos tüneteit.
1. táblázat | Laktázt termelő baktériumok [15]

\begin{tabular}{l}
\hline Probiotikumok \\
\hline Bifidobacterium breve \\
Bifidobacterium infantis \\
Bifidobacterium longum \\
Lactobacillus acidophilus \\
Lactobacillus casei \\
Lactobacillus bulgaricus \\
Lactobacillus rhamnosus \\
Streptococcus thermophilus \\
\hline Kórokozók \\
\hline Escherichia coli \\
Klebsiella pneumoniae \\
Enterobacter speciesek \\
Serratia marcescens \\
Citrobacter speciesek \\
\hline
\end{tabular}

Számítások alapján 50 g laktózból bakteriális fermentáció révén 17 liter hidrogén keletkezik: ennek legnagyobb részét felhasználja a többi bélbaktérium [13]. Más számítás szerint in vitro széklet jelenlétében 1 gramm glükózból $100 \mathrm{ml} \mathrm{H}_{2}$ keletkezik [14]. A Salmonella, Shigella, Proteus, Yersinia törzsek nem termelnek laktázt, de az általuk kiváltott gastroenteritis másodlagos LI-t okozhat [15].

\section{Epidemiológia}

Az LI a leggyakoribb felszívódási zavar: előfordulása a genetikai és környezeti tényezők hatása miatt egyenetlen. Az LI gyakoriságát minden kontinensen és számos populációban felmérték, ezek alapján két csoport különböztethető meg:

a) a felnőttkori primer laktázhiány gyakori (a populáció 60-90\%-a): arab országok, Izrael, ciprusi görögök, Dél-Olaszország, Thaiföld, Indonézia, Kína, Korea, bantu négerek, Alaszka, Kanada, Egyesült Államok, egyes indián törzsek;

b) laktázperzisztens etnikai csoportok (a lakosság csupán 2-30\%-a laktázhiányos: Észak-Európa, Afrika, Indiában Punjab állam és Új-Delhi környezete) [1].

Magyarországon az első felmérést Czeizel Endre (1935-2015) és mtsai végezték: 1984-ben 820 egészséges egyénen 50 g laktózterhelés után a laktózmalabszorpciót 37\%-osnak észlelték. Az arány 30\% volt a nyugati, $40 \%$ az északkeleti származású csoportban és 50\%-os a romáknál. A felmérés a Volkswagen Művek alapítványának támogatásával történt [5]. 1988-1990 között a II. Belgyógyászati Klinikán 108 betegben 51,8\%-ban észlelték az LI-t [6]. A 2014-es kérdőíves felmérésben 
15187 egyénnél a férfiak 9,4\%-ában, a nők 12,8\%-ában valószínúsítettek LI-t: vélhetóleg e módszer alábecsüli a betegség prevalenciáját [16].

\section{Genetika}

A laktáz gén a 2. kromoszóma hosszú karján helyezkedik el (2p2lq). Mérete 49,5-55 kilobázis és 17 exont tartalmaz $[3,17,18]$. Aktivitását transzkripcionális és poszttranszkripcionális folyamatok szabályozzák: ennek következtében a laktáz a születés előtt aktiválódik és a szoptatás befejeződése után fokozatosan csökken. A géntől a kromoszóma vége felé 14 és 22 kilobázis távolságra helyezkedik el az MCM6 gén, amelynek 13. intronján keletkeznek a polimorfizmusok: ezek az intestinalis hámsejtekben a riporter gén fokozott expressziójához vezetnek, és így laktóztoleranciát okoznak. Az MCM6 gén termékei a DNS-helikázok, a replikációt szabályozó fehérjék. A génen két laktázt szabályozó régió található, ezek közül az -13910-es régióról in vitro kimutatták, hogy a laktáz gén transzkripciójának promotere.

A laktázperzisztencia 5-10\%-os biológiai előnyt jelent a környezethez való alkalmazkodásban és ezzel a szelekció egyik legerősebb megnyilvánulása, mivel a tej jelentős tápanyag- és kalciumforrás [19]: ez ellentmond James van Gundia Neel (1915-2000) „takarékos gén” ( „thrifty gene") elméletének (1962), miszerint a fejlődés során az ismétlődó éhínségeket a takarékos génnel rendelkező

2. táblázat | A laktáz gén polimorfizmusainak gyakorisága [2, 17]

\begin{tabular}{|c|c|c|}
\hline Polimorfizmus & Ország & Gyakoriság (\%) \\
\hline \multirow[t]{12}{*}{ LCT-13910 C>T } & Amerikai Egyesült Államok & 74,6 \\
\hline & Svédország & 73,7 \\
\hline & Új-Zéland & 72 \\
\hline & Hollandia & 69 \\
\hline & Finnország & 58,1 \\
\hline & Ausztria & 53,0 \\
\hline & Lengyelország & 43,9 \\
\hline & Magyarország & 35,9 \\
\hline & Brazília & 34,0 \\
\hline & Olaszország & 11,3 \\
\hline & India & 6,6 \\
\hline & Kína & 0 \\
\hline \multirow[t]{2}{*}{ LCT-13915 T>G } & Szaúd-Arábia & 48,9 \\
\hline & Jordánia & 39,1 \\
\hline \multirow[t]{2}{*}{ LCT-14010 G>C } & Tanzánia & 31,9 \\
\hline & Kenya & 27,9 \\
\hline LCT-13907 C>G & Szudán & 20,6 \\
\hline LCT-22018 G>A & Kína & 18 \\
\hline LCT-13910 CC & Kína & 6,8 \\
\hline LCT-14009 T>G & Szudán & 6,6 \\
\hline
\end{tabular}

egyének élték át, akik a bevitt táplálékot gazdaságosabban használták fel [20].

Emberben a leggyakoribb polimorfizmus a 13910-es bázispárban a $\mathrm{T}$ és $\mathrm{C}$ kicserélődése: ennek gyakorisága országonként változik (2. táblázat). TT allél esetén a laktáz szintézise nem csökken fiatalkorban; TC allél a heterozigóta állapotnak felel meg, idősebb korban okozhat enyhe tünetekkel járó LI-t. Ha mindkét locuson $\mathrm{C}$ allél van, a laktáz enzim szintézise fokozatosan csökkent és LI alakul ki. TT és TC allél esetében is társulhatnak más genetikai eltérések, illetve megjelenhet a másodlagos LI.

Szintén gyakori a G/A (-22018) mutáció is, de ennek rutinszerú meghatározása még nem szokásos. Több más polimorfizmust leírtak: ezek fóképp távol-keleti országokban jelentősek.

Szegedi genetikus kutatócsoport a jelenkori egyéneken és honfoglalás kori csontokból PCR-rel határozta meg a polimorfizmusokat. Csontokban a C/C allél $87 \%$, a C/T 4\%, a T/T 9\%-ban volt jelen - ez ázsiai származásra utal, a 181 jelenkori egyénben az arányok 39\%, $50 \%$ és 11\%: ez utóbbiak megegyeznek a környező országok lakosságában észleltekkel, ami viszont a keveredésre utal. Ugyanaz a szerzőcsoport C/C-13910 genotípus gyakoriságát 37\%-nak találta: az egyének többségében a $\mathrm{H}_{2}$-teszt pozitív volt $[21,22]$.

\section{A laktózintolerancia intestinalis és extraintestinalis manifesztációi}

Az LI típusos tüneteit a laktóz felszívódási zavara okozza: a laktóz a duodenumból a jejunumba jut és ozmotikus hatása révén hasmenést okoz, majd a distalis ileumban és colonban a baktériumok, a fent említett gázok és savak okozzák a puffadást és bélgörcsöket. A panaszok erőssége és az elfogyasztott tejcukor mennyisége nincs arányban egymással: egyes betegeknél kis mennyiségú tejcukor (3 gramm) jelentős panaszokat okoz, másoknál 1-2 pohár tej tünetmentesen fogyasztható. A fokozott bélmotilitás (terhesség, hyperthyreosis) LI tüneteit is erősítik. A panaszok értelmezését tovább bonyolítja, hogy azokat okozhatja a tejfehérje, illetve a tejben lévő jelentős mennyiségü zsír is [1]. Az angol irodalomban megkülönböztetik a laktózmalabszorpciót, amely lehet tünetmentes, bár vizsgálatokkal kimutatható, a laktózintolerancia viszont a tünetekkel járó tejcukor-érzékenységet jelenti $[1,2,17]$.

Akárcsak a coeliakia, az LI a típusos tüneteken túl számos extraintestinalis panaszt okoz: ezeket a 3. táblázatban tüntetjük fel. Gyakorta diagnosztikai problémát jelentenek, különösen, ha az intestinalis tünetek enyhék/ hiányoznak $[2,17]$.

A leggyakrabban előforduló felnőttkori primer LI (elsődleges felnőttkori hypolactasia) autoszomális recesszíven öröklődő kórkép. A másodlagos LI tünetei azonosak, a kiváltó betegség rendezésével megszünik/enyhül (4. táblázat), kivéve a mütétek következtében fellépő eseteket. A veleszületett laktázhiányt az 1950-1960-as 
A laktózintolerancia intestinalis és extraintestinalis tüneteinek gyakorisága $[1,3,17]$

\begin{tabular}{llll}
\hline Intestinalis tünetek & $\%$ & Extraintestinalis tünetek & $\%$ \\
\hline Hasi fájdalom & $80-100$ & Fejfájás & $70-85$ \\
Puffadás & 100 & Memóriazavar & 80 \\
Flatulentia & $70-100$ & Fáradékonyság & $60-65$ \\
Bélkorgás & $50-100$ & Izomfájdalom & 70 \\
Hasmenés & $70-80$ & Ízületi fájdalom & $50-70$ \\
Székrekedés & 30 & Allergia (eczema, & $30-40$ \\
& & pruritus, rhinitis, & \\
& & sinusitis) & $10-24$ \\
Hányinger & $50-70$ & Szívritmuszavar & 20 \\
Hányás & $60-80$ & Enuresis & \\
\hline
\end{tabular}

években írták le (Holzel-, Duncan- és Darling-szindróma), és súlyos újszülöttkori felszívódási zavarral jár [2, $3]$.

\section{Diagnózis}

Az LI diagnózisának módszerei invazívak és nonivazívak. Elsőként az invazív módszerek jelentek meg: ezek kellemetlenek voltak, különösen gyermekeknél, ezért helyüket átadták az 1970-es években a kilégzési teszteknek, ezekhez társult az utóbbi években a genetikai vizsgálat.

\section{Invazín módszerek}

A vékonybél-biopsziát 1954-ben sebészeti úton végezték coeliakia kimutatására, 1956-ban a koreai háború veterán ezredese, William Holmes Crosby (1914-2005) vezette be a róla elnevezett kapszulát, amelyet vakon kellett levezetni; ezt Charles Debray Párizsban fejlesztette tovább oly módon, hogy az endoszkóppal lehessen mintát venni. A vak módszer előnyösebb, mert a Treiz-ligamentum környékéról lehet mintát venni, ahol a laktáz aktivitása a legmagasabb. A biopsziából a laktázaktivitás meghatározására 1963-ban a chicagói egyetemen dolgoztak ki módszert, amely később módosításokkal elterjedt és ezzel sikerült először igazolni LI-ben a laktázaktivitás csökkenését (hypolactasia) vagy hiányát (alactasia) [23]. A biopszia előnye, hogy kimutatja a nyálkahártya egyéb patológiás elváltozásait is. Utóbb a laktázaktivitást glükóz-oxidáz-módszerrel határozták meg, kimutatva, hogy a jejunumban kétszer magasabb, mint a duodenumban. Kidolgozták a kolorimetriás gyorstesztet is [24], amely postbulbaris duodenalis biopsziából 20 perc alatt méri az aktivitást, érzékenysége 95\%, fajlagossága $100 \%$, eredménye $83 \%$-ban egyezik a $\mathrm{H}_{2}$-kilégzési tesztével [25]. Kimutatták, hogy a laktáz aktivitásának csökkenése a nyálkahártyában nem folytonos, a genetikai eltérések sincsenek mindenütt jelen, jelezve, hogy a betegségben epigenetikus tényezők is szerepet játszanak [24].
4. táblázat | A másodlagos laktózintolerancia okai

Gastroenteritis (virális, bakteriális)
Coeliakia
Cystás fibrosis
Proteinkalória-malnutritio
Whipple-kór
Intestinalis lymphomák, lymphangiectasia
Abetalipoproteinaemia
Gyulladásos bélbetegségek
Irritábilis bél
Kemoterápia
Vírushepatitis
Giardia lamblia
Rosacea, dermatitis herpetiformis

Rövid bél szindróma

Gyomorreszekció, totális gastrectomia

Cholecystectomia

Whipple-mütét

Proctocolectomia

Székletvizsgálat. A székletben ürülő diszacharidok mérése tájékoztatást ad azok felszívódásának mértékéról. A széklet pH-meghatározásából következtetnek a bakteriális fermentáció által keletkezett savak mennyiségére: $\mathrm{pH}=5,5$ alatti érték a rövid láncú zsírsavak ürülésére jellemző. E teszteket a gyermekgyógyászatban használták [26].

Az orális laktóztolerancia-tesztet az 1960-as években vezették be. A többszörös vérvétel kényelmetlenné teszi, eredményét befolyásolja a gyomor-bél motilitás és glükózanyagcsere, ezért az esetek 25-35\%-ában álpozitív vagy álnegatív eredményt ad $[1,17,26]$. Ritkán a glükóz + galaktóz együttes mérése orális terhelés után javítja a módszer pontosságát [24].

A vizelet galaktóz meghatározása a galactosemiás gyermekek kivizsgálásából került a felnőttkori LI diagnosztika módszerei közé. A vizelet galaktóz- és laktóztartalmát 50 gr laktózterhelés után 3 órán át határozták meg, az értékeket a kreatininszinthez arányították. Ma már ritkán használják [26].

\section{Noninvazín módszerek}

Tünetorientált diagnózis. Az LI kórisméje megállapítható a tünetekből, ezért a kórelőzmény felvételénél részletesen ki kell kérdezni a tej és tejtermékek fogyasztása után fellépő tüneteket. Ebben segíthetnek a kérdőívek. Kontrollált tanulmányokban észlelték, hogy a típusos tünetek alapján az LI az esetek 80\%-ában biztonsággal kórismézhető [27, 28]. 


\section{Kilégzési tesztek}

Az emésztés során termelődő gázokat 1925-ben kezdték tanulmányozni, de csak az 1960-as évek élettani kutatásai igazolták: az emésztés és a kilélegzett levegő összetétele között összefüggés van. Sokáig a bélgázok összetételét és koncentrációját a flatusból határozták meg: e célból a rectumba gumi szélcsövet vezettek be és az így nyert anyagból végezték a meghatározásokat. Az LI kimutatására a kilélegzett levegőből először az izotópos módszereket dolgozták ki. 1969-ben japán munkacsoport ${ }^{14} \mathrm{C}$-vel jelzett laktózzal végzett terhelés után a ${ }^{14} \mathrm{CO}_{2}$-t mért [29], holland kutatók ezt a stabil ${ }^{13} \mathrm{C}$-izotópos jelöléssel helyettesítették: a 4 órás ${ }^{13} \mathrm{CO}_{2}$ kumulatív mennyisége és a jejunalis biopsziából mért laktáz aktivitása között pozitív összefüggés volt, sőt a $\mathrm{H}_{2}$-teszttel összehasonlítva érzékenysége $84 \%$, fajlagossága 96\% volt, szemben az utóbbi 68\% és 89\%-os értékével [30]. A radioaktív izotóp használatának ellenzése és a tömegspektrometria drágasága miatt e tesztek nem terjedtek el.

A $\mathrm{H}_{2}$-kilégzési teszt egyszerüsége és pontossága révén az LI-diagnózis arany standardja. A tesztet 1968-ban dolgozta ki a minnesotai egyetemen Michael D. Levitt, felismerve, hogy a kilélegzett $\mathrm{H}_{2}$ mennyisége arányos a bakteriális fermentáció által keletkező hidrogén mennyiségével. Vizsgálatait előbb patkányon, majd emberen végezte. A páciens 3-6 óráig egy polivinil vezetéken át egy 30 literes tartályba lélegzett; a tüdőben és tartályban lévő levegő térfogatát héliumdilúciós módszerrel határozták meg, a hidrogént gázkromatográfiával mérték alapszinten, majd 5, 10, 20, 25, 50 és 100 g szénhidrát adása után kiszámították a dózis-válasz értékeket [31]. Ennek elődje a svéd szerzők által 1957-ben bevezetett ilealis aspiráció [32]: az ileumba 2,5 mm vastag polivinil csövet vezettek és az aspirátumból a szénhidrátok, zsírok és amiláz koncentrációját mérték, és a $\mathrm{H}_{2}$ mennyisége és az ileumban a glükóz koncentrációja fordított arányban volt - a beteget és vizsgálót egyaránt próbára tevő vizsgálat lehetett.

A hidrogénszelektív üvegelektródot 1909-ben kísérletezte ki egy német és egy lengyel kémikus: a múszert a karlsruhei kémiai társaság előtt mutatták be röviddel azután, hogy Sören P. L. Sorensen (1868-1939) bevezette a pH fogalmát. 1922-ben hasonló, alkáli szilikátból készült elektródot készítettek. Az 1970-1980-as években kidolgozták a gáznemü, molekuláris hidrogénszenzorok több típusát: az elektronika haladásával ezeket miniatürizálták, ez a vizsgálatot lényegesen egyszerúsítette, de időtartama továbbra is 3 óra maradt [33].

Az elmúlt években számos vizsgálati protokollt dolgoztak ki, amelyben 20, 25, 50 vagy 100 g laktóz adása után 20 percenként mérik a hidrogénkoncentrációt: az emelkedés mértékéből és időbeli eloszlásából (korai?, késői?) következtetni lehet az LI jellegére. Nincs azonban összefüggés a kilélegzett hidrogén mértéke és a panaszok intenzitása között.

Ha a vékonybél-biopsziával mint arany standarddal vetik össze, a $\mathrm{H}_{2}$-kilégzés érzékenysége és fajlagossága ré- gebbi adatok szerint közel 100\% [34, 35]. Egy 2012-es metaanalízisben 17 kontrollált tanulmány alapján érzékenysége 88\% (KT: 85-90), fajlagossága 85\% (KT: 8287) volt [36]. Antibiotikumok, prokinetikumok szedése álnegatív eredményt adhat.

Magyarországon a $\mathrm{H}_{2}$-kilégzés módszerét 1983-ban a pécsi I. Belklinikán vezették be Beró Tamás és mtsai [37], miután 1976-1981 között elektrokémiai detektorral múködő készüléket fejlesztettek ki. Gyermekeknél Bodánszky Hedvig a fővárosi I. Gyermekklinikán értékelte ki a módszert [38], felnőtteknél Herszényi László és mtsai 1987-1989-ben a II. Belklinikán szereztek tapasztalatot [6]. A nehézkesen használható, a Budapesti Müszaki Egyetem által kifejlesztett készüléket felváltották a kompakt, digitalizált, beteg- és felhasználóbarát berendezések. Bár az irodalomban legpontosabbnak az $50 \mathrm{mg}$ laktózterhelést tartják [34], a hazai szakmai protokoll a 20 grammos tesztet javasolja [39].

\section{Metánkilégzési teszt}

A bélflórában a Methanobrevibacter smithii és Methanosphaera stadtmanae képezi a $\mathrm{CH}_{4}$ fó forrását: jelentősége, hogy azon egyének, akiknél a metánképző baktériumok vannak túlsúlyban, a $\mathrm{H}_{2}$-kilégzés álnegatív lelet. A bélben képződött metán felszívódik, de a vérben kevésbé oldódik, és a tüdőben a gázcserével kiürül. A felnőttek 30-60\%-a metánképző [40]. Az utóbbi években több módszert dolgoztak ki a kilélegzett metán mérésére (gázkromatográfia, tömegspektrometria, lézerspektrometria, szelektív ionfluxus mérése). A hidrogén és metán együttes kimutatása is lehetséges [41].

Szegeden az MTA kutatóintézetében innsbrucki kutatók közremúködésével kísérleti jelleggel fotoakusztikus spektroszkópiás szenzorral sikerült mérni a kilélegzett metánt, ergometriás terheléssel kimutatva annak függőségét a ventiláció-perfúzió arányától [42]. A következő években várható, hogy e bonyolult készülékek olcsóbb változatai bekerülnek a gyakorlatba, hozzájárulva az LI és más felszívódási zavarok pontosabb diagnózisához.

\section{Genetikai teszt}

A laktáz gén C/T-13910 polimorfizmusát kinetikus polimeráz láncreakcióval lehet kimutatni: a tesztet 2003ban vezették be, miután Finnországban azonosították az eltérést. Ma több hazai genetikai laboratóriumban térítéses alapon végzik. A genetikai teszttel összehasonlítva, a $\mathrm{H}_{2}$-kilégzési teszt szenzitivitása $88 \%$, specificitása $95 \%$ [43]. A diagnosztikában a két vizsgálat kiegészíti és nem helyettesíti egymást: a genetikai teszt a betegségre való hajlamot jelzi, amely a környezeti tényezők függvényében lehet, hogy megnyilvánul vagy sem, a $\mathrm{H}_{2}$-kilégzés a klinikailag manifeszt betegséget igazolja: ez lehet elsődleges felnőttkori hypolactasia vagy másodlagos LI. 


\section{Laktózintolerancia és gyulladásos bélbetegségek (IBD)}

1925-ben feltételezték, hogy a tej fogyasztása CU-t okozhat, és ennek hátterében 1943-ban fehérjeallergiát sejtettek [44], de ezt utóbb cáfolták [45]. Az 1960-as években esetbemutatásokban és kisebb betegcsoportokban az intestinalis laktázaktivitás mérésével [46], illetve laktózterheléssel kimutatták, hogy CU-ban az LI 8-35\%ban fordul elö, CD-ben viszont a gyakoriság 60\%-os. Egy 2009-es tanulmányban laktóz-, fruktóz- és laktulózterhelés után $\mathrm{H}_{2}$-tesztet végeztek. CD-ben $42 \%$-ban, CU-ban 40\%-ban, IBS-ben csak 27\%-ban igazoltak LI-t [47]. Genetikai teszttel 2011-ben mutatták ki, IBD-ben a C/C(-13910), azaz laktózérzékeny genotípus gyakorisága 70\%-os, jóval magasabb, mint a régebbi tanulmányokban: ezen esetek $\mathrm{H}_{2}$ - és metánkilégzési tesztje is pozitív [48]. Pozitív $\mathrm{H}_{2} /$ metán kilégzési teszt gyakori a CT/TT genotípusokban is, jelezve, hogy az LI patogenezisében más genetikai tényezők is szerepet játszhatnak. A laktózterhelés után jelentkező fokozott metántermelés felhívja a figyelmet, hogy a metánt termelő baktériumoknak szerepük lehet az IBD patogenezisében.

\section{Laktózintolerancia és irritábilis bél szindróma}

Az LI és IBS kapcsolata a két betegség gyakorisága miatt ellentmondásos. Földrajzi régióktól függően az IBS-betegek 4-78\%-ában LI is fellép, másrészt a tejcukorérzékenyeknél a visceralis szenzitivitás növekedése miatt az IBS kockázata magasabb. $\mathrm{H}_{2}$-kilégzéssel az IBS-betegek 24-45\%-ában mutatható ki LI. Az LI gyakorisága az IBS hasmenéses, székrekedéses és kevert formájában azonos. Kérdőíves felméréssel az LI gyakorisága 58\% volt IBSben és 28\% a kontrollcsoportban. IBS-ben szükséges az LI keresése $\mathrm{H}_{2}$-kilégzési teszttel. Genetikai teszttel még nem történt ez irányú felmérés $[35,47]$. A két betegség változatos prevalenciája miatt együttes előfordulásuk populációnként ingadozik.

\section{Laktózintolerancia és coeliakia}

Az LI és gluténérzékenység együttes előfordulását 1965ben írták le gyermekekben és olyan gyakorinak találták, hogy lisztérzékenységben laktózmentes étrendet javasoltak [49]. Utóbb vékonybél-biopsziával és laktóztolerancia-teszttel coeliakiás gyermekek 8,5\%-ában igazolták az LI-t [50]. A H $\mathrm{H}_{2}$-kilégzést elvégezték 79, újonnan diagnosztizált coeliakás betegben és 71 egészséges önkéntesnél: az LI gyakorisága 10\%, illetve 15\% volt [47]. Egy olasz tanulmányban 92 , szövettanilag igazolt coeliakiás és 188 kontrollgyermeknél a C/T (-13910) és G/A (-22018) homozigóta status gyakorisága azonosan $77,2 \%$, illetve $71,7 \%$ volt, és a polimorfizmusok ellenére gluténmentes diéta mellett a gyermekek tünetmentesek voltak, mivel feltehetően a bélflóra kompenzálta a laktázhiányt [51]. Coeliakiában az LI gyakran másodlagos. Gluténmentes diétával másodlagos LI-ben a tejcukor-érzékenység megoldódik. Amennyiben a szénhidrát-felszívódási zavar primer, a megfelelő diétás kezelés javasolt (glutén+laktózmentes étrend).

A dolgozat tervezett II. része az LI hosszú távú anyagcsere-következményeiről (csontritkulás, daganatok), a probiotikumok szerepéról, a diétáról és az enzimpótlás lehetőségeirôl, valamint az LI-ben szenvedő betegek szociális ellátásáról értekezik.

Anyagi támogatás: A közlemény megírása anyagi támogatásban nem részesült.

A cikk végleges változatát a szerző elolvasta és jóváhagyta.

Érdekeltségek: A szerzőnek nincsenek érdekeltségei.

\section{Köszönetnyilvánítás}

A szerző köszönettel tartozik Józan Jolánnak a kézirat szövegszerkesztéséért, Szilágyi Annának (Semmelweis Egyetem, Élettani Intézet) az irodalom beszerzéséért és Douglas Arnott úrnak (EDMF Language Services, Budapest) az angol összefoglaló lektorálásáért.

\section{Irodalom}

[1] Högenauer, C., Hammer, H. F.: Maldigestion and malabsorbtion, Lactose malabsorbtion. In: Feldman, M., Friedman, L. S., Brandt, L. J. (eds.): Sleisinger and Fordtran's Gastrointestinal and Liver Disease. Pathophysiology/Diagnosis/Management. 10th ed. Elsevier-Saunders, Philadelphia, 2015.

[2] Campbell, A. K., Waud, J. P., Matthews, S. B.: The molecular basis of lactose intolerance. Sci. Prog., 2005, 88(3), 157-202.

[3] Kretchmer, N.: Memorial lecture: Lactose and lactase - a historical perspective. Gastroenterology, 1971, 61(6), 805-813.

[4] Demény, P., Dán, S.: Lactose intolerance in adults. [A felnőttkori laktóz intoleranciáról.] Orv. Hetil., 1968, 109(12), 622-624. [Hungarian]

[5] Flatz, G., Czeizel, E., Flatz, D. S.: Prevalence of adult lactose malabsorption in Hungary. [A felnőttkori elsődleges laktóz-malabszorbció prevalenciája Magyarországon.] Orv. Hetil., 1984, 125(3), 147-151. [Hungarian]

[6] Herszényi, L., Miskolczi, K., Tolnay, E., et al.: Experience with hidrogen $\left(\mathrm{H}_{2}\right)$ breath test. [Hidrogén $\mathrm{H}_{2}$-kilégzési vizsgálattal szerzett tapasztalataink.] Orv. Hetil., 1992, 133(39), 24832487. [Hungarian]

[7] Plimmer, R. H.: On the presence of lactase in the intestines of animals and on the adaptation of the intestine to lactose. J. Physiol., 1906, 35(1-2), 20-31. http://www. Journal of Physiology archivum

[8] Mendel, L. B., Mitchell, P. H.: Chemical studies on growth. I. The inverting enzymes of the alimentary tract, especially in the embryo. Am. J. Physiol., 1907, 20, 81-96.

[9] Peaker, M.: The mammary gland in mammalian evolution: a brief commentary on some of the concepts. J. Mammary Gland Biol. Neoplasia, 2002, 7(3), 347-353.

[10] http://www. en. wikipedia. org/wiki/Milk

[11] Curry, A.: Archaeology: The milk revolution. Nature, 2013, 500(7460), 20-22. 
[12] MacConkey, A.: Lactose-fermenting bacteria in feaces. J. Hyg. (Lond.), 1905, 5(3), 333-379.

[13] De Vrese, M., Stegelmann, A., Richter, B., et al.: Probiotics - compensation for lactase insufficiency. Am. J. Clin. Nutr., 2001, 73(2 Suppl.), 421S-429S.

[14] Flourié, B., Florent, C., Rambaud, J. C.: Bases rationelles des test respiratoires. In: Bernier, J. J. (ed.): Gastro-entérologie, Vol 1. Flammarion Médecine Sciences, Paris, 1984.

[15] Lactase activity of live bacteria. http://www. bio-kult. com/research-technical/134/lactase activity

[16] Bajor, J.: Estimation of lactose intolerance in the Hungarian population, possible consequences of nutritional changes. [Laktóz intolerancia felmérése a magyar lakosság körében, a táplálkozás megváltoztatásának lehetséges következményei.] Magyar Gasztroenterológiai Társaság 57. Nagygyúlése, Siófok, 2015, Abstract, 9/93. [Hungarian]

[17] Mattar, R., Mazo, D. F., Carrilho, F. J.: Lactose intolerance: diagnosis, genetic and clinical factors. Clin. Exp. Gastroenterol., $2012,5,113-121$.

[18] Swallow, D. M.: Genetics of lactase persistence and lactose intolerance. Annu. Rev. Genet., 2003, 37, 197-219.

[19] Gibson, G.: Human evolution: thrifty genes and the dairy queen. Curr. Biol., 2007, 17(8), R295-R296.

[20] Neel, J. V.: Diabetes mellitus: a "thrifty" genotype rendered detrimental by progress? Am. J. Hum. Genet., 1962, 14(4), 353362 .

[21] Nagy, D., Tömöry, G., Csányi, B., et al.: Comparison of lactase persistence polymorphism in ancient and present-day Hungarian populations. Am. J. Phys. Antropol., 2011, 145(2), 262-269.

[22] Nagy, D., Bogácsi-Szabó, E., Várkonyi, A., et al.: Prevalence of adult-type hypolactasia as diagnosed with genetic and lactose hydrogen breath tests in Hungarians. Eur. J. Clin. Nutr., 2009, 63(7), 909-912.

[23] Dablqvist, A.: Method for the assay of the intestinal disaccharidases. Analyt. Biochem., 1963, 7(1), 18-25.

[24] Kuokkanen, M., Myllynieni, M., Vaubkonen, M., et al:: A biopsybased quick test in the diagnosis of duodenal hypolactasia in upper diagnostic endoscopy. Endoscopy, 2006, 38(7), 708-712.

[25] Ojetti, V., La Mura, R., Zucco, M. A., et al.: Quick test: a new test for the diagnosis of duodenal hypolactasia. Dig. Dis. Sci., 2008, 53(6), 1589-1592.

[26] Saavedra, J. M.: Carbohydrate malabsorbtion. In: Brandt, L. J. (ed.): Clinical Practice of Gastroenterology, Vol. 2. Churchill Livingstone, Philadelphia, 1996.

[27] Jellema, P., Schellevis, F. G., van der Windt, D. A., et al.: Lactose malabsorbtion and intolerance: a systematic review on the diagnostic value of gastrointestinal symptoms and self-reported milk intolerance. QJM, 2010, 103(8), 555-572.

[28] Nicklas, T. A., Qu, H., Hughes, S.,O., et al.: Self-perceived lactose intolerance results in lower intakes of calcium and dairy foods and is associated with hypertension and diabetes in adults. Am. J. Clin. Nutr., 2011, 94(1), 191-198.

[29] Ueda, H., Sasaki, ., Iio, M., et al.: Diagnosis of lactase deficiency by exhaled air counting method using Cl4-lactose. Naika, 1969, $24(4), 725-728$.

[30] Hiele, M., Ghoos, $\Upsilon$., Rutgeerts, P., et al.: ${ }^{13} \mathrm{CO}_{2}$ breath test using naturally ${ }^{13} \mathrm{C}$-enriched lactose for detection of lactase deficiency in patients with gastrointestinal symptoms. J. Lab. Clin. Med., 1988, 112(2), 193-200.

[31] Bond, J. H. Jr., Lewitt, M. D.: Use of pulmonary hydrogen $\left(\mathrm{H}_{2}\right)$ measurements to quantitate carbohydrate absorbtion. Study of partially gastrectomized patients. J. Clin. Invest., 1972, 51(5), 1219-1225.

[32] Borgström, B., Dahlqvist, A., Lundh, G. H., et al.: Studies of intestinal digestion and absorbtion in the human. J. Clin. Invest., 1957, 36(10), 1521-1536.

[33] http://www. Glass electrode. en.wikipedia. org/wiki/Glass_ electrode
[34] Romagnuolo, J., Schiller, D., Bailey, R. J.: Using breath tests wisely in a gastroenterology practice: an evidence-based review of indications and pitfalls in interpretation. Am. J. Gastroenterol., 2002, 97(5), 1113-1126.

[35] Rana, S. V., Malik, A.: Breath tests and irritable bowel syndrome. World J. Gastroenterol., 2014, 20(24), 7587-7601.

[36] Marton, A., Xue, X., Szilágyi, A.: Meta-analysis: the diagnostic accuracy of lactose breath hydrogen or lactose tolerance tests for predicting the North European lactase polymorphism C/T13910. Aliment. Pharmacol. Ther., 2012, 35(4), 429-440.

[37] Beró, T., Past, T., Tapsonyi, Z., et al.: Clinical significance of $\mathrm{H}_{2}$ determination in breath. A new method for the detection of carbohydrate malabsorbtion (preliminary report). [A lehelet $\mathrm{H}_{2}$ meghatározás klinikai jelentősége.] Orv. Hetil., 1983, 124(2), 67-69. [Hungarian]

[38] Bodánszky, H., Soutter, V., Leleiko, N.: Determination of hydrogen in the exhaled air as a diagnostic method in carbohydrate metabolism disorders. [Lehelet hydrogén meghatározás mint diagnosztikus eszköz szénhidrát felszívódási rendellenességekben.] Orv. Hetil., 1981, 122(33), 2039-2040. [Hungarian]

[39] Döbrönte, $Z .: \mathrm{H}_{2}$ breath test in the investigation of carbohydrate malabsorbtion. In: Lonovics, J., Nemesánszky, E., Simon, L., et al. (eds.): Varro's Gastroenterology. [A szénhidrát-malabszorbció vizsgálata $\mathrm{H}_{2}$-kilégzési teszttel. In: Lonovics, J., Nemesánszky, E., Simon, L., et al. (szerk.): Varró, V. Gasztroenterológia.] Medicina Könyvkiadó, Budapest, 2011. [Hungarian]

[40] De Lacy Costello, B. P., Ledochowski, M., Ratcliffe, N. M.: The importance of methane breath testing: a review. J. Breath Res., 2013, 7(2), 024001

[41] Enko, D., Rezanka, E., Stolba, R., et al.: Lactose malabsorbtion testing in daily clinical practice: a critical retrospective analysis and comparison of the hydrogen/methane breath test and genetic test (C/T-13910 polymorphism) results. Gastroenterol. Res. Pract., 2014, 2014, ID 464382. doi: 10. 1155/2014/464382

[42] Szabó, A., Ruzsanyi, V., Unterkofler, K., et al.: Exhaled methane concentration profiles during exercise on an ergometer. J. Breath Res., 2015, 9(1), 016009. doi: 10. 1088/1752/9/1/016009.

[43] Krawczyk, M., Wolska, M., Schwartz, S., et al.: Concordance of genetic and breath tests for lactose intolerance in a tertiary referral centre. J. Gastrointestin. Liver Dis., 2008, 17(2), 135-139.

[44] Andresen, A. F.: Ulcerative colitis - an allergic phenomenon. Am. J. Dig. Dis., 1942, 9, 91-98.

[45] Struthers, J. E. Jr., Singleton, J. W., Kern, F. Jr.: Intestinal lactase deficiency in ulcerative colitis and regional ileitis. Ann. Intern. Med., 1965, 63(2), 221-228.

[46] Newcomer, A. D., McGill, D. B.: Incidence of lactase deficiency in ulcerative colitis. Gastroenterology, 1967, 53(6), 890-893.

[47] Barrett, J. S., Irving, P. M., Shepherd, S. J., et al.: Comparison of the prevalence of fructose and lactose malabsorption across chronic intestinal disorders. Aliment. Pharmacol. Ther., 2009, $30(2), 165-174$.

[48] Eadala, P., Matthews, S. B., Waud, J. P., et al.: Association of lactose sensitivity with inflammatory bowel disease - demonstrated by analysis of genetic polymorphism, breath gases and symptoms. Aliment. Pharmacol. Ther., 2011, 34(7), 735-746.

[49] Arthur, A. B., Clayton, B. E., Cottom, D. G., et al.: Importance of dissacharide intolerance in the treatment of coeliac disease. Lancet, 1966, 287(7430), 172-174.

[50] McNeish, A. S., Sweet, E. M.: Lactose intolerance in childhood coeliac disease. Assessment of its incidence and importance. Arch. Dis. Child., 1968, 43(230), 433-437.

[51] Basso, M. S., Luciano, R., Ferretti, F., et al.: Association between celiac disease and primary lactase deficiency. Eur. J. Clin. Nutr., 2012, 66(12), 1364-1365.

(Buzás György Miklós dr., Budapest, Mester u. 45., 1095 e-mail: drbgym@gmail.com) 